\title{
A systemic review of existing serological possibilities to diagnose canine osteoarthritis with a particular focus on extracellular matrix proteoglycans and protein
}

\author{
M. Shahid ${ }^{1}$, G. Manchi ${ }^{1}$, P. Slunsky ${ }^{1}$, O. Naseer ${ }^{3}$, A. Fatima ${ }^{4}$, \\ B. Leo ${ }^{1}$, J. Raila ${ }^{2}$ \\ ${ }^{1}$ Faculty of Veterinary Medicine, Small Animal Clinic, Free University Berlin, Germany \\ ${ }^{2}$ Institut fur Ernahrungswissenschaft, University of Potsdam, 14558 Nuthetal OT Bergholz-Rehbrucke, Germany \\ ${ }^{3}$ Factulty of Veterinary Sciences, Department of Clinical Medicine and Surgery, UVAS, Lahore, Pakistan \\ ${ }^{4}$ International Medical School, Tianjin Medical University, China
}

\begin{abstract}
Extra-cellular matrix (ECM) components are important and their stabilization is significant in maintaining normal healthy joint environment. In osteoarthritis (OA), ECM components are altered and indicate disease progression. The joint ECM is composed of proteoglycans (aggrecan, perlecan, inter $\alpha$-trypsin inhibitor), glycoproteins (fibronectin, lubricin, COMP) and collagen types (most abundantly collagen type II) which represent structural and functional transformation during disease advancement. ECM investigation revealed significant biomarkers of OA that could be used as a diagnostic and therapeutic tool in different canine orthopedic diseases. This review deliberates our current findings of how the components of ECM change at the molecular level during disease progression in canine OA.
\end{abstract}

Key words: extra-cellular matrix, canine osteoarthritis, biomarker, synovial fluid, proteomix analysis

\section{Introduction}

Osteoarthritis (OA) is one of the most prevalent causes of joint degeneration, lameness, pain, and chronic physical disability in dogs despite advanced diagnostic approaches and modern therapies. Canine diseases, such as: elbow dysplasia, hip dysplasia (HD), poly-arthritis and cranial cruciate ligament (CCL) rupture together with medial meniscus are major risk factors of OA. OA requires intensive and long term treatment putting financial strain on pet owners. For canine CCL disease and stifle joint OA alone, the annual cost was estimated to be several billion dollars (Wilke et al. 2005).

Why are dogs important in OA research? Animal models were used in order to study human OA. In fact, these experimental models provide valuable advantages and significant information in comparison 
with human OA research. The dog model is one of the frequently used animal models for OA exploration, since dogs have anatomical, clinical and therapeutic similarities to human OA along with arthroscopy possibilities (Cook et al. 2010). Therefore, these features make the dog an ideal species to study human OA. For this purpose, OA was developed through surgical induction of CCL (Pond and Nuki 1973) and meniscal transection (Luther et al. 2009) in dogs. Other surgical and chemical induction models were also delineated (Cook et al. 2010). Due to the close resemblance of the dog model to human OA, we focused only on the dog OA model rather than other species, such as sheep, goat, rat and horse.

Biomarkers are commonly used to diagnose diseases. However, reliable biomarkers for canine OA have yet to be discovered. Therefore, one of the goals of ongoing studies in the field of veterinary and human orthopedics is to discover biomarkers for early diagnosis and therapy of OA. Biomarkers are measurable indicators for the specific biological state. Particularly, they reflect the presence, risk, or stage of a disease. In the clinic, biomarkers can be implemented as a diagnostic, prognostic and therapeutic tool (Rifai et al. 2006). Biomarkers point out the pharmacological response to therapeutic interventions. Biomarkers can be categorized into "dry" and "wet soluble" biomarkers. Radiographs, magnetic resonance imaging (MRI), computed tomography (Spector et al. 1992) and ultrasound are dry biomarkers, whereas genetic (DNA, RNA) and biochemical (protein, protein peptides, carbohydrate and metabolites) molecules are wet soluble biomarkers (Kraus et al. 2011). Radiography is usually used in diagnosing and monitoring of dog OA. MRI and CT scans are more sensitive than radiography. Nevertheless, their implementation is associated with high cost and the problem of availability. Likewise, Arthroscopy provides a magnificent internal view of articular cartilage but this is an invasive technique.

During OA, catabolic activities increase compared to anabolism in articular cartilage, resulting in significant loss of extra-cellular matrix (ECM) components. The major components of cartilage are proteoglycans, collagens, hyaluronan, and glycosaminoglycans along with non-collagen glycoprotein components such as: lubricin and cartilage oligomatrix protein (COMP). The loss of ECM is a main characteristic of cartilage destruction in OA. Hence, investigation of bio-chemical changes in ECM is believed to be an important factor in OA pathology. Due to these changes, a few discharged fragments could ultimately be assessed in urine, blood plasma, serum and synovial fluid (Oliviero et al. 2009). Multiple serological assays have been developed for the detection of OA. They permit the detection of fragments, including cytokines, proteoglycans, collagen and many others. These robust parameters represent disease severity and therapeutic interventions. Similarly, ELISA is also used to examine the biochemical marker, where antibodies react against different antigens in different biological fluids. The literature provides a number of publications on the subject of serological assays for OA biomarker research in dogs. The current review summarized all of the canine OA biomarkers in Table 1 regarding protein and carbohydrate.

\section{Collagen type II}

Collagen type II is one of the major elements of the cartilage ECM, structurally composed of three identical collagen h1 chains in a triple helix, exceptionally N-, and C-telopeptides. The key function of this collagen is to safeguard the cartilage. This collagen is abnormally degraded in OA. One study measured SF antibody titers of collagen type I and II in stifle joint disease CCL rupture (partial or complete) accompanied with OA. The antibody titers of collagen type I and II were significantly increased in SF, especially in dogs with secondary OA as compared to the control dog group. Augmentations to collagen autoantibodies in SF were not precise for the kind of joint disorder. It was doubtful that anti-collagen antibodies had an initial dynamic role in CCL weakness (De Rooster et al. 2000).

Matrix metalloproteinase (MMP) family members play a pivotal role in collagen type II degradation (Chung et al. 2004). In dog OA cartilage, mRNA expression of MMP -2 and -9 was found to be elevated (Clements et al. 2009). Moreover, there was clear evidence that elevated canine MMP -2 and -9 activities were present in CCL rupture SF (Boland et al. 2014) (Rabillard et al. 2012). Different members of the MMP family (MMP collagenases $-2,-3,-9$ and -13 ) involved in initial collagen degradation (Settle et al. 2010) (Hegemann et al. 2003). Therefore, MMP -2, -3 and -9 are potential biomarkers in canine OA SF.

$\mathrm{C} 2 \mathrm{C}$ is a concrete product resulting from collagen type II breakage. In an ACLT model, collagen type II neoepitope was increased in canine urine and its concentration was elevated in canine cartilage explant after IL-1f-stimulation. Nevertheless, the collagenase inhibitors suppressed the elevation of collagen type II neoepitope (Matsukawa et al. 2013). Consequently, this was shown to be a progressive step towards a therapeutic approach. The collagenases break collagen type II at approximately one quarter of the length of the molecule away from the C-terminus. As a consequence of this cleavage, 1 and $\mathrm{L}$ length 
Table 1. Biomarkers used clinically in canine OA, including their specificity and method of detection.

\begin{tabular}{|c|c|c|c|c|c|c|c|c|}
\hline \multirow{2}{*}{$\begin{array}{l}\text { Biomarker } \\
\text { type }\end{array}$} & \multirow{2}{*}{ Fragment } & \multicolumn{3}{|c|}{ Specificity } & \multirow{2}{*}{$\begin{array}{l}\text { Sample } \\
\text { type }\end{array}$} & \multirow{2}{*}{$\begin{array}{l}\text { Number of } \\
\text { animals }\end{array}$} & \multirow{2}{*}{$\begin{array}{l}\text { Method of } \\
\text { detection }\end{array}$} & \multirow{2}{*}{ Reference } \\
\hline & & OA & Diseased & $\overline{\text { Healthy }}$ & & & & \\
\hline \multirow{4}{*}{$\begin{array}{l}\text { Collagen } \\
\text { Type II }\end{array}$} & Autoantibodies & $\bar{\uparrow}$ & $\uparrow \mathrm{CCL}$ & & SF & 82 dogs & ELISA & (De Rooster et al. 2000) \\
\hline & $\mathrm{C} 2 \mathrm{C}$ & & $\uparrow \mathrm{MCD}$ & & $\mathrm{SF}$ & $\begin{array}{l}19 \text { diseased } \\
\text { dogs } \\
+8 \text { control } \\
\text { dogs }\end{array}$ & ELISA & (Prink et al. 2010) \\
\hline & $\begin{array}{c}\text { Col2-3/4C long } \\
\text { mono and } \\
\text { CTX-II }\end{array}$ & $\begin{array}{c}\text { 个 in Stifle } \\
\text { joint } \\
\text { injury }\end{array}$ & & & $\mathrm{SF}$ & $\begin{array}{l}20 \text { large } \\
\text { mixed } \\
\text { breeds }\end{array}$ & ELISA & (Matyas et al. 2004) \\
\hline & $\begin{array}{l}\text { Neo-epitope } \\
\text { TIINE }\end{array}$ & & $\begin{array}{l}\uparrow \text { After } \\
\text { canine } \\
\text { menisce- } \\
\text { ctomy }\end{array}$ & & Urine & & $\begin{array}{l}\text { TIINE } \\
45-\mathrm{mer} \\
\text { assay }\end{array}$ & (Settle et al. 2010) \\
\hline \multirow[t]{2}{*}{ COMP } & COMP & $\uparrow$ & & & Serum & $\begin{array}{c}16 \text { OA dogs } \\
+5 \text { control } \\
\text { dogs }\end{array}$ & ELISA & (Fujiki et al. 2007) \\
\hline & COMP & & & $\begin{array}{l}\uparrow \text { after } \\
\text { intense } \\
\text { exercise }\end{array}$ & $\begin{array}{c}\text { SF } \\
\text { Serum }\end{array}$ & & ELISA & (Qi and Changlin 2006) \\
\hline Fibronectin & $(\mathrm{V}+\mathrm{C})^{-}$ & $\uparrow$ & & & SF & $\begin{array}{c}26 \text { OA dogs } \\
+22 \text { control } \\
\text { dogs }\end{array}$ & ELISA & (Steffey et al. 2004) \\
\hline \multirow[t]{4}{*}{ Hyaluronan } & & & $\uparrow \mathrm{CCL}$ & & SF & $\begin{array}{c}\text { Surgically } \\
\text { induced OA } \\
\text { in } 6 \text { dogs } \\
+21 \text { control } \\
\text { dogs }\end{array}$ & ELISA & (Venable et al. 2008) \\
\hline & & $\downarrow$ & & & SF & 49 dogs & ELISA & (Plickert et al. 2013) \\
\hline & & & $\downarrow \mathrm{HD}$ & & Serum & $\begin{array}{c}25 \text { diseased } \\
\text { dogs }+98 \\
\text { control } \\
\text { dogs }\end{array}$ & ELISA & $\begin{array}{c}\text { (Nganvongpanit et al. } \\
\text { 2008) }\end{array}$ \\
\hline & & & $\begin{array}{l}\downarrow \text { induced } \\
\text { OA }\end{array}$ & & & 12 dogs & ELISA & (Budsberg et al. 2006) \\
\hline \multirow[t]{4}{*}{$\begin{array}{l}\text { Chondroitin } \\
\text { sulfate }\end{array}$} & WF6 & & $\uparrow \mathrm{HD}$ & & Serum & $\begin{array}{c}25 \text { diseased } \\
\text { dogs }+98 \\
\text { control } \\
\text { dogs }\end{array}$ & ELISA & $\begin{array}{c}\text { (Nganvongpanit et al. } \\
\text { 2008) }\end{array}$ \\
\hline & $3 \mathrm{~B} 3$ & & $\downarrow \mathrm{HD}$ & & Serum & $\begin{array}{c}25 \text { diseased } \\
\text { dogs }+98 \\
\text { control } \\
\text { dogs }\end{array}$ & ELISA & $\begin{array}{c}\text { (Nganvongpanit et al. } \\
\text { 2008) }\end{array}$ \\
\hline & $3 \mathrm{~B} 3$ & & $\uparrow C C L$ & & $\mathrm{SF}$ & $\begin{array}{c}8 \text { diseased } \\
\text { dogs }+24 \\
\text { control } \\
\text { dogs }\end{array}$ & ELISA & $\begin{array}{l}\text { (Johnson et al. 2001) } \\
\text { (Johnson et al. 2002) }\end{array}$ \\
\hline & $7 \mathrm{D} 4$ & & $\uparrow \mathrm{CCL}$ & & $\mathrm{SF}$ & & ELISA & $\begin{array}{l}\text { (Johnson et al. 2001) } \\
\text { (Johnson et al. 2002) }\end{array}$ \\
\hline \multirow[t]{2}{*}{$\begin{array}{l}\text { Keratan } \\
\text { sulfate }\end{array}$} & & & $\begin{array}{c}\uparrow \text { induced } \\
\text { OA }\end{array}$ & & Serum & $12 \operatorname{dogs}$ & ELISA & (Budsberg et al. 2006) \\
\hline & 5D4 & $\downarrow$ & & & $\mathrm{SF}$ & & ELISA & $\begin{array}{c}\text { (Matyas et al. 2004) } \\
\text { (Hegemann et al. 2002) }\end{array}$ \\
\hline
\end{tabular}


cont. Table 1

\begin{tabular}{|c|c|c|c|c|c|c|c|c|}
\hline \multirow{2}{*}{$\begin{array}{l}\text { Biomarker } \\
\text { type }\end{array}$} & \multirow{2}{*}{ Fragment } & \multicolumn{3}{|c|}{ Specificity } & \multirow{2}{*}{$\begin{array}{l}\text { Sample } \\
\text { type }\end{array}$} & \multirow{2}{*}{$\begin{array}{c}\text { Number of } \\
\text { animals }\end{array}$} & \multirow{2}{*}{$\begin{array}{l}\text { Method of } \\
\text { detection }\end{array}$} & \multirow{2}{*}{ Reference } \\
\hline & & $\mathrm{OA}$ & Diseased & $\overline{\text { Healthy }}$ & & & & \\
\hline \multirow[t]{3}{*}{ Aggrecan } & $\begin{array}{c}\text { aggrecan } \\
846 \text { epitope }\end{array}$ & & $\uparrow \mathrm{CCL}$ & & Serum & $\begin{array}{l}20 \text { mixed } \\
\text { breed } \\
\text { dogs }\end{array}$ & $\begin{array}{c}\text { Radio } \\
\text { immno assay } \\
\text { (RIA) }\end{array}$ & (Matyas et al. 2004) \\
\hline & $\begin{array}{c}\text { ARGN and } \\
\text { AGEG peptides } \\
\text { degradation } \\
\text { fragments }\end{array}$ & & $\begin{array}{l}\uparrow \text { After } \\
\text { canine } \\
\text { menisce- } \\
\text { ctomy }\end{array}$ & & SF & & $\begin{array}{c}\text { Aggrecan } \\
\text { neo-epitope } \\
\text { assays based } \\
\text { on liquid } \\
\text { chromato- } \\
\text {-graphy }\end{array}$ & (Settle et al. 2010) \\
\hline & $\begin{array}{c}\text { Aggrecan } \\
\text { generated } \\
\text { catabolites } \\
\text { BC-3 } \\
\text { BC-14 }\end{array}$ & & $\uparrow \mathrm{OA}$ & & $\mathrm{SF}$ & $\begin{array}{l}\text { Early and } \\
\text { late OA } \\
\text { dogs }\end{array}$ & $\begin{array}{l}\text { Western blot } \\
\text { analysis }\end{array}$ & (Innes et al. 2005) \\
\hline YKL40 & $\begin{array}{c}\text { Chitinase like } \\
\text { molecules }\end{array}$ & & $\begin{array}{l}\text { Anterior } \\
\text { cruciate } \\
\text { ligament }\end{array}$ & & $\begin{array}{c}\text { Knee } \\
\text { cartilage }\end{array}$ & & $\begin{array}{c}\text { Trans- } \\
\text {-criptase } \\
\text { PCR } \\
\text { analysis }\end{array}$ & (Lorenz et al. 2005) \\
\hline MPO & Myeloperoxidase & & $\begin{array}{c}\text { Fragment } \\
\text { medial } \\
\text { coronoid } \\
\text { process }\end{array}$ & & $\mathrm{SF}$ & & $\begin{array}{l}\text { MPO } \\
\text { assay }\end{array}$ & (Hurlbeck et al. 2014) \\
\hline MMP-2 & & & $\mathrm{CCL}$ & & $\mathrm{SF}$ & $\begin{array}{c}14 \text { CCL in } \\
\text { large breeds } \\
+11 \text { control } \\
\text { dogs }\end{array}$ & ELISA & (Boland et al. 2014) \\
\hline
\end{tabular}

fragments are released. The 1 fragment holds both C2C neo-epitope or Col 2-3/4C (long monomers) particular to collagen type II (Poole et al. 2004) and C1, $2 \mathrm{C}$ or Col2-3/4C (short monomers) that are present in both type I and type II collagen (Billinghurst et al. 1997). C2C is basically present in hyaline cartilage, intervertebral disc, and in minute quantities in other tissues (Poole et al. 2004).

This raises a relevant question whether OA pathogenesis is accompanied by oxidative stress. The Pond-Nuki model was designed to check the role of oxidative stress in OA development. OA was experimentally induced by anterior cruciate ligament transection in 7 dogs. Analysis of preoperative and postoperative (interval of 30, 60 and 105 days) serum catalase displayed climax activity on day 60 . In contrast, malondialdehyde and $\mathrm{C} 2 \mathrm{C}$ concentration were increased uninterruptedly throughout the experiment. This indicates to a possible relation between oxidative stress and cartilage obliteration (Goranov 2007).

There was no strong evidence that $\mathrm{C} 2 \mathrm{C}$ could be applied as a diagnostic biomarker in canine serum and urine. A cross-sectional study was conducted to compare $\mathrm{C} 2 \mathrm{C}$ concentration in canine serum, urine, and
SF, between clinically developed stifle joint OA in CCL disease and a control group. Fragment correlation was checked with disease severity. C2C or Col 2-3/4C concentration was measured using a commercially available ELISA kit. Lameness, osteophytosis and joint effusion were important $(\mathrm{p}<0.05)$ parameters, recorded in a naturally occurring diseased group. However, there was no significant correlation between $\mathrm{C} 2 \mathrm{C}$ and clinical stifle joint $\mathrm{OA}(\mathrm{p}>0.05)$. $\mathrm{C} 2 \mathrm{C}$ was not a cause of OA development, and therefore could not be used as a clinical biomarker (Hayashi et al. 2009). However, decreased levels of C2C and hyaluronic acid were better indicators of clinical disease improvement in canine serum after hip OA (Vilar et al. 2016). In a beagle OA model, platelet-rich plasma and adipose-derived mesenchymal stem cells played a substantial role in the improvement of ECM (collagen and glycosaminoglycan) (Yun et al. 2016).

In contrast to the above observations, another study noticed that $\mathrm{C} 2 \mathrm{C}$ ( $\mathrm{Col} 2-3 / 4 \mathrm{C})$ concentration was increased in canine synovial fluid ( $\mathrm{Chu}$ et al. 2002). A cross-sectional clinical study was conducted on canine elbow dysplasia with medial coronoid 
disease (Valiyaveettil et al. 2005). The mean (+ SD) $\mathrm{C} 2 \mathrm{C}$ concentration in MCD dogs was remarkably higher $(112.3+24.8 \mathrm{ng} / \mathrm{ml})$ than in the control group $(76.1+16.9 \mathrm{ng} / \mathrm{ml} ; \mathrm{P}<0.05)$. Therefore, $\mathrm{C} 2 \mathrm{C}$ concentration in SF might be a potential biomarker for diagnosis of the degree of articular cartilage damage with MCD (Prink et al. 2010).

Coll2-1 and Coll2- $1 \mathrm{NO}_{2}$ are the degradation products of collagen type II that can indicate both disease succession and activity (Henrotin et al. 2007). A study was conducted to measure Coll2-1 and Coll2- $1 \mathrm{NO}_{2}$ during OA development after anterior cruciate ligament transection in dogs. Immunoassays depicted high serum concentrations with $\mathrm{P}$ values $<0.001$ and $<0.05$ respectively. The level of Coll2 $-1 \mathrm{NO}_{2}$ showed a constant increase and reached its peak level after 6 and 8 weeks of surgery. It was also associated with osteophyte formation and reflected oxidative stress in OA (Henrotin et al. 2012).

The carboxy-terminal cross-linked fragments of collagen type II (CTX-II) showed an age dependent pattern. CTX-II was increased in SF (Hurlbeck et al. 2014) and serum (Schoenherr et al. 2010) of juvenile dogs. In a knee transection canine OA experimental model, CTX-II concentration in SF was remarkably higher in an affected joint compared to a contra-lateral control joint (Matyas et al. 2004).

Thiol-dependent enzyme cathepsin $\mathrm{K}$ reacts in a normal acidic $\mathrm{pH}$ environment that was evaluated to be produced by OA chondrocytes and was thought to play a major role in cartilage breakdown and aggrecans (Konttinen et al. 2002). Cathepsin K was involved in hyaline cartilage destruction as well as calcified cartilage and sub-chondral bone resorption at the earliest stage of dog OA (Pelletier et al. 2004). In OA cartilage, cathepsin $\mathrm{K}$ protein and its gene expression were remarkably increased in the superficial zone in comparison with normal cartilage (Pelletier et al. 2005). In the canine OA model, treatment with licofelone (non-steroidal anti-inflammatory drug) (Pelletier et al. 2004) and tiludronate (bisphosphonate) (Moreau et al. 2011) considerably decreased cathepsin $\mathrm{K}$ activity. Cathepsin $\mathrm{K}$ inhibitor (SB-553484) treatment reduced subjective gross and calculated degeneration scores by $29 \%$ and $46 \%$ respectively in dogs. Histo-pathologic analysis indicated that total tibial degeneration score decreased about $21 \%$. In urine samples, biomarkers of collagen type I and II were decreased, which is a direct outcome of bone and cartilage degradation (Connor et al. 2009). These results appeared to show that cathepsin $\mathrm{K}$ played a key role in joint disability and lameness and its level decreased after treatment. It is generally believed that collagen fragmentation occurs during $\mathrm{OA}$ and these fragments were investigated as valuable diagnostic biomarkers. Hence, Cathepsin $\mathrm{K}$, a less abundant component of the cartilage, can be a better diagnostic biomarker in relation to collagen type II fragments.

Collagen type I h2-chain (COL1A2) and collagen type III h1-chain (COL3A1) increased in OA cartilage relative to the control cartilage. In this study, elevated MMP-2, -9 and -13 gene expressions were assessed by reverse transcriptase polymerase chain reaction. Radio-graphically assessed OA severity could be correlated with cartilage gene expression (Clements et al. 2009). The relative increase in matrix metalloproteinase with collagens displayed its anabolic effect on collagens in canine OA cartilage. It is also interesting to know that MMP-13 was thought to be a major collagenase in OA cartilage and was basically responsible for collagen type II cleavage (Kevorkian et al. 2004).

\section{Glyco-proteins}

\section{Cartilage oligomeric matrix protein (COMP)}

COMP, also known as thrombospondin 5, is present abundantly in the synovium, tendon, cartilage, serum, and SF. COMP not only interacts with collagen types (I, II and IX) but also supports collagen types I and II in fibril formation. Therefore, it plays a fundamental role in the assembly, solidarity and safeguarding of the cartilage ECM (Chu et al. 2015).

Magnetic resonance imaging (MRI) is a useful supplementary tool accompanied with different practical biomarkers in order to detect articular cartilage degradation in dogs at its earlier stage. An elevated level of COMP was noticed in serum after intensive training indicating a potential relationship of COMP with knee cartilage degradation measured with MRI $(\mathrm{P}<0.01)$. However, the SF COMP value did not show any difference between normal and abnormal MR imaging ( $P>0.05)$ (Qi and Changlin 2007). In human OA, COMP correlation with disease severity was estimated by MRI (Hunter et al. 2007) but it did not exhibit any relationship with inflammatory biomarkers (Skoumal et al. 2006).

What is the effect of exercise on COMP? Strong physical activities, for example a marathon race, increased the concentration of COMP in serum (Andersson et al. 2006). Similarly, a higher COMP level was recorded in serum and SF after strenuous exercise, which ultimately reached its climax level after 4 and 6 weeks respectively in dogs. Meanwhile, changes in knee cartilage were evaluated with MRI examination (Qi and Changlin 2006). An increased COMP level at its earlier stage was observed, which might be the re- 
sult of cartilage injury. Therefore, COMP could be considered as a sensitive biomarker in articular cartilage injury.

In one study, the value of COMP concentration was found to be significant $(\mathrm{P}=0.019)$ in $\mathrm{OA}$ dog;s serum compared to a control group. After intramuscular treatment with poly-sulfated glycosaminoglycan (PSGAG), COMP concentration was decreased $(\mathrm{p}<0.001)$ in OA dogs in comparison with healthy dogs. The analyzed improvement in lameness might be a response to therapy (Fujiki et al. 2007). Thus COMP could be used to monitor disease therapy and also as a diagnostic biomarker in OA dogs.

Canine COMP concentration was elevated in serum $(44.9, \mathrm{~g} / \mathrm{ml})$ and synovial fluid $(401.7, \mathrm{~g} / \mathrm{ml})$ compared to the control group (31.3 and $298.79, \mathrm{~g} / \mathrm{ml}$ respectively) after naturally occurring OA (Misumi et al. 2002). COMP value was also increased after experimentally induced OA (meniscectomy) (Lindhorst et al. 2000) (Carlson et al. 2002). There was therefore clear evidence that COMP concentration was raised initially after meniscectomy in SF and remained the same during 12 weeks of follow up (Lindhorst et al. 2000). One study indicated decreased COMP concentration in SF after meniscal injury and correlation was observed between COMP and canine meniscal injury (Girling et al. 2006).

\section{Fibronectin}

Fibronectin (FN), a higher molecular weight glycoprotein, is involved in a variety of cellular processes, including migration, adhesion, proliferation and differentiation. It is a major component of ECM, uses as a substrate for cell attachment (Bager et al. 2016). Chondrocytes are the main source of FN in OA cartilage. It was shown that total $\mathrm{FN}$ was increased directly with extra domain $\mathrm{B}(\mathrm{ED}-\mathrm{B}+) \mathrm{FN}$ in OA cartilage. FN, together with collagen type VI, might perform a role in matrix-matrix cohesion and cell-matrix adhesion on agarose-cultured chondrocytes extracted from normal adult canine articular cartilage. Immunohistochemistry together with dual channel microscopy and digital image processing showed co-localization between FN and collagen type VI in the pericellular microenvironment regardless of a retaining mechanism in articular cartilage chondrocytes (Scanzello et al. 2015).

The subcuticular connective tissues are most sensitive in dogs. Matrix metalloproteinase inhibitors (MMPi) were administered in dogs, which ultimately became the cause of connective tissue alternation known as "fibrodysplasia". Fibrodysplastic tissues showed significant activation and secretion of col- lagens (type III and I) after ultra-structural analysis. Immuno-histo-chemistry indicated increased levels of $\mathrm{FN}$ and transforming growth factor $\mathrm{f}$ (Westwood et al. 2009). Therefore, MMPi-induced fibrodysplasia is also a risk factor of musculoskeletal problems in dogs.

Fibronectin protein folds itself into a series of globular homologous repetitions of three different types I, II and III, comprises of 45, 60, and 90 amino acids respectively. Different cell types produce different multiple iso-forms of FN encoded by a single gene. There are two iso-forms of $\mathrm{FN}$, one containing the $\mathrm{V}$ domain and another containing the ED-A domain employed in canine OA and human RA respectively. The $(\mathrm{V}+\mathrm{C})^{-}$is an iso-form of FN that lacks I-10, III-15 and domain V segments. Furthermore, it accounts for $55-80 \%$ of total FN tissue in articular cartilage (Stoffels et al. 2013). Although (V+C) - iso-form was present solely in cartilage, its presence in synovial fluid indicated its cartilage origin and proved it as a potential biomarker in order to observe canine OA. An elevated level of $(\mathrm{V}+\mathrm{C})$ - was noticed in canine $\mathrm{SF}$ in a contra-lateral knee suffering from CCL rupture. Thus, it might represent earlier changes in knee joint injury compared to a healthy joint. Nevertheless, there were alterable measurements between the control and diseased group. This was possible due to joint effusion in the affected knee joint that made it a less applicable clinical biomarker (Steffey et al. 2004). On the other hand, FN iso-form comprised with ED-A domain was more expressed after the stimulation of cytokines, hormones, growth factors and stress in different pathological diseases, including rheumatoid arthritis (RA) (Przybysz et al. 2009). This iso-form was particularly over expressed in SF, plasma and articular cartilage of RA patients in comparison to $\mathrm{OA}$ or fibrous RA. For this reason it is a suitable biomarker in RA disease (Miyamoto et al. 2002) (Przybysz et al. 2009). In RA patients, a direct correlation was noticed between ED-A and progressive joint destruction in SF. Therefore, ED-A in SF might be an indicator of joint destruction during RA (Przybysz et al. 2009).

Fibronectin fragments were not identified in canine SF and serum. However, numerous FN fragments (N-terminal FN) were identified in human OA and RA, which were produced by ADAM-8-mediated after FN cleavage at the Ala/Val site. The resulting FN fragments VYQP and VRAA neo-epitopes were therefore recommended as potential biomarkers. These neo-epitopes were further analyzed in OA cartilage and were co-localized in the area of aggrecan loss. VYQP neo-epitopes induced cartilage destruction (Zack et al. 2006) (Zack et al. 2009). Rac1 is needed for FN fragments to induce signaling and to increase chondrocyte MMP-13 production. Rac1 has the ability to stimulate MMP-13 production so that it 
can perform an important function in OA cartilage destruction (Long et al. 2013). Furthermore, pro-inflammatory factors (IL-1f, IL-6 or FN fragments) stimulate meniscus cells to produce more metalloproteinases as well as catabolic gene expression. In fact, stimulation of the meniscus can enhance the OA development process after joint injury; there is an increased production of chemokines, cytokines and matrix degrading enzymes (Stone et al. 2014).

\section{Lubricin}

Lubricin, a lubricating and superficial zone glycoprotein, is encoded by the PRG4 gene (Reesink et al. 2016). It has a central protective role in cartilage against friction-induced wear. Recent research has revealed its important role both in cell adhesion and proliferation. It has various functions in articular joints and tendons, such as surface protection and synovial cell growth (Szychlinska et al. 2016).

The role of lubricin is quite understood in human OA (Musumeci et al. 2014) and in other species, including the rabbit (Elsaid et al. 2005), rat (Musumeci et al. 2015), sheep (Young et al. 2006), equine (Reesink et al. 2016) and guinea pig (Wei et al. 2010). Lubricin is widely distributed in different structures; synovial fluid, articular cartilage, synovial fibroblasts, synoviocytes, meniscus, tendons and ligaments (Szychlinska et al. 2016).

The lubricating ability was evaluated by arthrotripsometer oscillating latex opposed to polished glass in in vitro analysis. In OA patients, the lubricating tendency of lubricin was decreased in synovial fluid compared to the healthy group (Jay et al. 2004). After a joint injury, lubricin synthesis was increased (Jones et al. 2009) in cartilage that was further isolated from the synovial fluid in OA and RA patients. However, liquid chromatography-MS analyses indicated that RA patients contained different sialylation compared to OA patients in which lubricin was enriched with mono-sialylated types (Estrella et al. 2010). The sialylation up-regulation indicated an inflammatory reaction during which sialyic acids residues gained the ability to increase lubrication.

In an animal model, treatment together with the combination of lubricin protected articular cartilage and prevented the process of OA development (Flannery et al. 2009); its potential bio-therapeutic implementation in OA is recommended (Bao et al. 2011). Lubricin played a significant role in reducing the gliding fraction by repairing the canine flexor digitorum prefunds tendon and maintaining tendon smoothness (Taguchi et al. 2009) (Zhao et al. 2014). However, its role in canine $\mathrm{OA}$ is yet to be evaluated.

\section{Hyaluronan}

Hyaluronic acid (HA) or hyaluronan, a polymer of molecular mass up to 10 Daltons, is produced by synovial fibroblasts and is composed of repeating disaccharidic units of D- glucuronic acid and $\mathrm{D}-\mathrm{N}$-acetyl-glucosamine. HA is part of the normal cartilage matrix where it has a central role in ECM stabilization together with aggrecan interaction. Moreover, HA has hydrodynamic properties and performs fundamental functions in lubrication and osmotic stability (Nusgens 2010). In an experimentally induced OA, HA has a suppressive character in reducing chondrocyte apoptosis (Echigo et al. 2006).

Two-dimensional electrophoresis analysis revealed hyaluronan-binding protein 2 (also known as plasma hyaluronan binding protein, PHBP), which has the ability to link with hyaluronan. This protein was decreased in OA dog serum (Gharbi et al. 2013) and displayed a strong attraction to negatively charged substances, including hyaluronic acid, heparin and dextran sulfate. PHBP has the ability to interact with glycosaminoglycans and, as a result, cuts matrix proteins, such as fibrinogen and fibronectin (Choi-Miura et al. 2001). Therefore, PHBP has a catabolic effect on fibronectin and generates different iso-forms in ECM (Steffey et al. 2004) (Przybysz et al. 2009).

During canine orthopedic diseases, the level of HA was lowered in serum (Nganvongpanit et al. 2008) and synovial fluid (Venable et al. 2008). In contrast to these findings, elevated serum (Sasaki et al. 2013) and decreased SF levels of HA were noticed in human OA (Li et al. 2009). In RA patients, a decreased HA level was found in SF (Kosinska et al. 2015) and an elevated concentration was noticed in serum (Pothacharoen et al. 2006). In addition, HA molecular weight was reduced in canine OA (Venable et al. 2008) similar to RA patients (Kosinska et al. 2015).

$\mathrm{HA}$ is a promising biomarker neither in human RA nor in canine OA. The circulating HA level varies with physical activity and diurnal periods, reducing its effectiveness as a reliable clinical biomarker (Engströum-Laurent and Hällgren 1987). Hyaluronan level decreased with the increase of disease severity and its concentrations were not so consistent in different OA stages; it is not therefore an ideal biomarker for diagnostic purpose (Plickert et al. 2013).

\section{Chondroitin Sulfate}

Chondroitin sulfate (CS) binds covalently with aggrecan, leucine-rich proteoglycans, biglycan and decorin in ECM. CS contains different sequences of 
$\mathrm{N}$-acetyl D-galactosamine $4 / 6 \quad$ sulphate and D-glucoronate residues, which are linked together (Simáneka et al. 2005). CS is a vital element in the joint where it prevents space narrowing, decreases joint swelling and effusion. It has an anti-inflammatory role in chondrocytes and synovial fluid by inhibiting nuclear translocation of nuclear factors ${ }_{k} B$ $\left(\mathrm{NF}_{-\mathrm{k}} \mathrm{B}\right)$ (Iovu et al. 2008).

In canine hip dysplasia, the two isotopes (WF6 and $3 \mathrm{~B} 3$ ) of $\mathrm{CS}$ were analyzed to evaluate the process of OA. The results showed that CS epitope WF6 level was higher $(p<0.01)$ and $3 B 3$ was lower $(p<0.05)$ in serum compared to the control group (Nganvongpanit et al. 2008). The highest level of WF6 CS epitopes indicated the process of joint degradation in OA, whereas a decreased level of 3B3 showed less synthesis of this isotope. It appears that imbalance of these isotopes aggravates the disease process.

There was a noteworthy increase of 3B3 and 7D4 epitopes after naturally or experimentally induced CCL rupture compared to normal SF. However, their relationship to disease severity made their clinical usage limited (Johnson et al. 2002). These epitopes reached their peak levels after several months due to CCL transaction and indicated a linear relationship with disease progression regardless of CCL intra-articular or extra-capsular reconstruction (Johnson et al. 2001).

\section{Keratan Sulfate}

Keratin sulfate (Stone et al. 2014) is an abundant element in aggrecan and thus much effort was made to develop a canine OA biomarker in the past. In humans, KS level in serum was not related to knee OA (Golightly et al. 2011). However, high serum KS level was observed in old knee trauma patients. Therefore, the serum level of KS in trauma patients represented articular cartilage damage (Wakitani et al. 2007). KS concentration fluctuated in canine SF due to severity of cartilage degradation while serum $\mathrm{KS}$ was increased after induced OA (Budsberg et al. 2006).

In SF, a lower level of KS 5D4 in canine OA was detected through ELISA and this indicated its inverse relationship with disease severity. The ratio of 5D4 $\mathrm{KS} / 3 \mathrm{~B} 3$ chondroitin sulfate was also decreased in SF in contrast with 3B3 (+/-) revealing metabolic changes in OA (Lindhorst et al. 2000) (Hegemann et al. 2002). Likewise, KS epitope 5D4 level was reduced in OA and RA in comparison with the healthy group (Spector et al. 1992). Tibial plateau osteotomy did not considerably change KS 5D4 expression, indicating that surgery had a minimum effect on proteoglycan metabolism (Girling et al. 2006). Tibial plateau osteotomy did not influence OA development. Current evidence shows that KS is not a clinically reliable biomarker due to its inverse relationship with disease progression and controversial research results.

\section{Aggrecan}

Aggrecan is the substantial proteoglycan of cartilage tissues and is responsible for hydrodynamic functions, including weight bearing and elasticity. Furthermore, aggrecan $(220 \mathrm{kDa})$ structure is made up of six domains: globular 1 (G1), inter-globular (IG), globular 2 (G2), KS, CS and globular 3 (G3) (Nia et al. 2015). Both canine knee fibro-cartilage and hyaline cartilage are dissimilar on a molecular basis, such as gene expression and spatial aggrecan distribution, and also on a concentration basis. These dissimilarities were analyzed using real time PCR, immuno-fluorescence microscopy and ELISA (anti-aggrecan G1 antibody) respectively (Valiyaveettil et al. 2005). In fact, aggrecan content decreased (40-50\%) after OA development in contrast to other small proteoglycans (biglycan, fibromodulin and decorin), which increased in canine cartilage (Liu et al. 2003) regardless of age. Collagen type II and aggrecan mRNA ratios changed in cartilage after experimentally induced OA (Matyas et al. 2002).

Aggrecan 846 epitope is present on intact aggrecan molecules and is linked with CS at the level of the G3 domain in cartilage. After a joint injury, epitope concentration changed in SF and indicated degenerative changes (Matyas et al. 2004). On the other hand, the level of epitope in serum increased, while KS remained unchanged (Matyas et al. 2004). The increase of aggrecan 846 epitope in serum indicated earlier joint injury; it could therefore be used as a diagnostic biomarker.

Aggrecan degradation plays an important role in $\mathrm{OA}$, in which newly formed $\mathrm{C}$ and $\mathrm{N}$ termini are produced after the cleavage of aggrecan by the reaction of matrix metalloproteinases (proteolytic enzymes) and aggrecanses respectively. $\mathrm{C}$ terminus containing GAG was released out of the matrix after the cleavage of the IG domain during aggrecan molecule breakdown. $\mathrm{N}$ terminus cleavage at the level of the Glu-Ala bond generated ARGN and AGEG peptides which were detected using polyclonal antibody (Gibson and Briggs 2016). ADAMTS -4 and -5 , also known as aggrecanase 1 and 2 respectively, produced fragments of aggrecan at five different points which were recognized in diseased cartilage (Arner 2002) (Nagase and Kashiwagi 2003). MMPs were also responsible for aggrecan cleavage (Struglics et al. 2006). The resulting 
products (ARGN and AGEG) were valuable degradation biomarkers only in canine SF. MMP-13 performed an active role in aggrecan degradation and its activity was reduced by using PF152 (MMP inhibitor) in dogs; this could ultimately decrease aggrecan peptides and cartilage lesions (Settle et al. 2010). The aggrecanases were actively involved in IGD cleavage at earlier stages in OA joints. BC-3 and BC-14 aggrecan metabolites (200-250Kd) were both able to differentiate between early and late stages of OA (Innes et al. 2005). However, MMPs mediated cartilage degradation at later stages of OA (Little et al. 2002).

\section{Conclusion}

In the last two decades, efforts to discover a practicable solution for the diagnosis of human and canine OA have intensified. Biomarkers detect cartilage proteoglycan degradation and their resulting fragments, in synovial fluid, serum, plasma and urine and can be used to diagnose the disease, monitor its progression, and to evaluate therapeutic response. Therefore, efforts were focused on biomarker development. Dogs are considered an ideal animal in OA research because dog OA models provide significant information regarding OA diagnosis, pathogenesis and treatment. Although outstanding work has been done towards clinical biomarker development, the discovery of a reliable biomarker for OA remains elusive.

Different proteoglycan biomarkers are discussed in this review paper to assess their specificity and clinical use in canine OA. Researchers started to focus on biomarker development from fragments of protein in ECM, which restricted further research process on OA. There is an urgent need to study other proteoglycans, such as perlecan and inter alpha trypsin inhibitor and their possible involvement in canine OA. The role of perlecan has already been appraised in human OA (Tesche and Miosge 2004).

Researchers are now focusing on proteomic analysis in OA; this method of research leads to more clarification of cartilage ECM structure and degradation, and scrutinizes more efficiently the proteins in SF, serum and urine. Proteomics analysis has proven itself as a milestone in developing a biomarker in OA until now. Electrophoresis analysis is carried out to analyze different proteins and peptides through matrix-assisted laser desorption ionization-imaging mass spectrometry (MALDI-MS/MS). These abundant proteins can be purified as diagnostic biomarkers through ELISA and western blotting analyses.

Biomarkers are an indicator of disease severity and therapeutic response; for example, the role of poly-sulfated glycosaminoglycan treatment was studied in OA and its effect on different biomarkers (COMP, MMP-2, MMP-9 and CRP) was also investigated (Fujiki et al. 2007). Biomarkers are a valuable tool in diagnosing OA at earlier and later stages. Additionally, their implementation for the treatment of OA is another positive aspect. For the future investigation of the biomarkers of $\mathrm{OA}$, integrating glycol-proteomics analysis of carbohydrate and protein structure should be included in combination rather than in isolation. Proteomics analysis was started earlier in humans than in dogs to resolve the OA problem; however, this analysis is very crucial in resolving OA in canines as well. Therefore, concerted efforts are required for proteomics analysis in canine OA.

\section{Acknowledgements}

It is acknowledged that the cost of publication of this article is paid by Free University Berlin, Germany.

\section{References}

Andersson M, Petersson I, Karlsson K, Jonsson EN, Mänsson B, Heinegärd D, Saxne T (2006) Diurnal variation in serum levels of cartilage oligomeric matrix protein in patients with knee osteoarthritis or rheumatoid arthritis. Ann Rheum Dis 65: 1490-1494.

Arner EC (2002) Aggrecanase-mediated cartilage degradation. Curr Opin Pharmacol 2: 322-329.

Bager C, Gudmann N, Willumsen N, Leeming D, Karsdal M, Bay-Jensen A, Høgdall E, Balslev I, He Y (2016) Quantification of fibronectin as a method to assess ex vivo extracellular matrix remodeling. Biochem Biophys Res Commun 478: 586-591.

Bao JP, Chen WP, Wu L (2011) Lubricin: a novel potential biotherapeutic approaches for the treatment of osteoarthritis. Mol Biol Rep 38: 2879-2885.

Billinghurst RC, Dahlberg L, Ionescu M, Reiner A, Bourne R, Rorabeck C, Mitchell P, Hambor J, Diekmann O, Tschesche H (1997) Enhanced cleavage of type II collagen by collagenases in osteoarthritic articular cartilage. J Clin Invest 99: 1534-45.

Boland L, Danger R, Cabon Q, Rabillard M, Brouard S, Bouvy B, Gauthier O (2014) MMP-2 as an early synovial biomarker for cranial cruciate ligament disease in dogs. Vet Comp Orthop Traumatol 27: 210-215.

Budsberg SC, Lenz ME, Thonar EJA (2006) Serum and synovial fluid concentrations of keratan sulfate and hyaluronan in dogs with induced stifle joint osteoarthritis following cranial cruciate ligament transection. Am J Vet Res 67: 429-432.

Carlson CS, Guilak F, Vail TP, Gardin JF, Kraus VB (2002) Synovial fluid biomarker levels predict articular cartilage damage following complete medial meniscectomy in the canine knee. J Orthop Res 20: 92-100. 
Choi-Miura NH, Saito K, Takahashi K, Yoda M, Tomita M (2001) Regulation mechanism of the serine protease activity of plasma hyaluronan binding protein. Biol Pharm Bull 24: 221-225.

Chu Q, Lopez M, Hayashi K, Ionescu M, Billinghurst R, Johnson K, Poole A, Markel M (2002) Elevation of a collagenase generated type II collagen neoepitope and proteoglycan epitopes in synovial fluid following induction of joint instability in the dog. Osteoarthritis Cartilage 10: 662-669.

Chu X, Wang J, Dou L, Zhao G (2015) Cartilage oligomeric matrix protein and matrix metalloproteinase-3 expression in the serum and joint fluid of a reversible osteoarthritis rabbit model. Genet Mol Res 14: 14207-14215.

Chung L, Dinakarpandian D, Yoshida N, Lauer-Fields JL, Fields GB, Visse R, Nagase H (2004) Collagenase unwinds triple-helical collagen prior to peptide bond hydrolysis. EMBO J 23: 3020-3030.

Clements DN, Fitzpatrick N, Carter SD, Day PJ (2009) Cartilage gene expression correlates with radiographic severity of canine elbow osteoarthritis. Vet J 179: 211-218.

Connor J, LePage C, Swift B, Yamashita D, Bendele A, Maul D, Kumar S (2009) Protective effects of a cathepsin $\mathrm{K}$ inhibitor, SB-553484, in the canine partial medial meniscectomy model of osteoarthritis. Osteoarthritis Cartilage 17: 1236-1243.

Cook J, Kuroki K, Visco D, Pelletier JP, Schulz L, Lafeber F (2010) The OARSI histopathology initiative-recommendations for histological assessments of osteoarthritis in the dog. Osteoarthritis Cartilage 18: S66-S79.

De Rooster H, Cox E, Bree HV (2000) Prevalence and relevance of antibodies to type-I and-II collagen in synovial fluid of dogs with cranial cruciate ligament damage. Am J Vet Res 61: 1456-1461.

Echigo R, Mochizuki M, Nishimura R, SasakI N (2006) Suppressive Effect of Hyaluronan on Chondrocyte Apoptosis in Experimentally Induced Acute Ostaoarthritis in Dogs. J Vet Med Sci 68: 899-902.

Elsaid K, Jay G, Warman M, Rhee D, Chichester C (2005) Association of articular cartilage degradation and loss of boundary-lubricating ability of synovial fluid following injury and inflammatory arthritis. Arthritis Rheum 52: 1746-1755.

Engströum-Laurent A, Hällgren R (1987) Circulating hyaluronic acid levels vary with physical activity in healthy subjects and in rheumatoid arthritis patients. Relationship to synovitis mass and morning stiffness. Arthritis Rheum 30: 1333-1338.

Estrella R, Whitelock J, Packer N, Karlsson N (2010) The glycosylation of human synovial lubricin: implications for its role in inflammation. Biochem J 429: 359-367.

Flannery CR, Zollner R, Corcoran C, Jones AR, Root A, Rivera-Bermúdez MA, Blanchet T, Gleghorn JP, Bonassar LJ, Bendele AM (2009) Prevention of cartilage degeneration in a rat model of osteoarthritis by intraarticular treatment with recombinant lubricin. Arthritis Rheum 60: 840-847.

Fujiki M, Shineha J, Yamanokuchi K, Misumi K, Sakamoto $\mathrm{H}$ (2007) Effects of treatment with polysulfated glycosaminoglycan on serum cartilage oligomeric matrix protein and C-reactive protein concentrations, serum matrix metalloproteinase- 2 and-9 activities, and lameness in dogs with osteoarthritis. Am J Vet Res 68: 827-833.
Gharbi M, Sanchez C, Mazzucchelli G, De Pauw E, Henrotin Y (2013) Identification of differential pattern of protein expression in canine osteoarthritis serum after anterior cruciate ligament transection: a proteomic analysis. Vet J 197: 848-853.

Gibson BG, Briggs MD (2016) The aggrecanopathies; an evolving phenotypic spectrum of human genetic skeletal diseases. Orphanet J Rare Dis 11: 86.

Girling S, Bell S, Whitelock R, Rayward R, Thomson D, Carter S, Vaughan-Thomas A, Innes J (2006) Use of biochemical markers of osteoarthritis to investigate the potential disease-modifying effect of tibial plateau levelling osteotomy. J Small Anim Pract 47: 708-714.

Golightly YM, Marshall SW, Kraus VB, Renner JB, Villaveces A, Casteel C, Jordan JM (2011) Biomarkers of incident radiographic knee osteoarthritis: do they vary by chronic knee symptoms? Arthritis Rheum 63: 2276-2283.

Goranov NV (2007) Serum markers of lipid peroxidation, antioxidant enzymatic defense, and collagen degradation in an experimental (Pond-Nuki) canine model of osteoarthritis. Vet Clin Pathol 36: 192-195.

Hayashi K, KIM SY, Lansdowne JL, Kapatkin A, Dejardin LM (2009) Evaluation of a collagenase generated osteoarthritis biomarker in naturally occurring canine cruciate disease. Vet Surg 38: 117-121.

Hegemann N, Kohn B, Brunnberg L, Schmidt M (2002) Biomarkers of joint tissue metabolism in canine osteoarthritic and arthritic joint disorders. Osteoarthritis Cartilage 10: 714-721.

Hegemann N, Wondimu A, Ullrich K, Schmidt MF (2003) Synovial MMP-3 and TIMP-1 levels and their correlation with cytokine expression in canine rheumatoid arthritis. Vet Immunol Immunopathol 91: 199-204.

Henrotin Y, Addison S, Kraus V, Deberg M (2007) Type II collagen markers in osteoarthritis: what do they indicate? Curr Opin Rheumatol 19: 444-450.

Henrotin Y, Martel-Pelletier J, Msika P, Guillou G, Deberg M (2012) Usefulness of specific OA biomarkers, Coll2-1 and Coll2-1NO 2, in the anterior cruciate ligament OA canine model. Osteoarthritis Cartilage 20: 787-790.

Hunter DJ, Li J, LaValley M, Bauer DC, Nevitt M, DeGroot J, Poole R, Eyre D, Guermazi A, Gale D (2007) Cartilage markers and their association with cartilage loss on magnetic resonance imaging in knee osteoarthritis: the Boston Osteoarthritis Knee Study. Arthritis Res Ther 9: R108.

Hurlbeck C, Einspanier R, Pfeil I, Bondzio A (2014) Evaluation of biomarkers for osteoarthritis caused by fragmented medial coronoid process in dogs. Res Vet Sci 96: 429-435.

Innes JF, Little CB, Hughes CE, Caterson B (2005) Products resulting from cleavage of the interglobular domain of aggrecan in samples of synovial fluid collected from dogs with early-and late-stage osteoarthritis. Am J Vet Res 66: 1679-1685.

Iovu M, Dumais G, Du Souich P (2008) Anti-inflammatory activity of chondroitin sulfate. Osteoarthritis Cartilage 16: S14-S18.

Jay GD, Elsaid KA, Zack J, Robinson K, Trespalacios F, Cha CJ, Chichester CO (2004) Lubricating ability of aspirated synovial fluid from emergency department patients with knee joint synovitis. J Rheumatol 31: 557-564. 
Johnson KA, Hart RC, Chu Q, Kochevar D, Hulse DA (2001) Concentrations of chondroitin sulfate epitopes 3B3 and 7D4 in synovial fluid after intra-articular and extracapsular reconstruction of the cranial cruciate ligament in dogs. Am J Vet Res. 62: 581-587.

Johnson KA, Hay CW, Chu Q, Roe SC, Caterson B (2002) Cartilage-derived biomarkers of osteoarthritis in synovial fluid of dogs with naturally acquired rupture of the cranial cruciate ligament. Am J Vet Res 63: 775-781.

Jones AR, Chen S, Chai DH, Stevens AL, Gleghorn JP, Bonassar LJ, Grodzinsky AJ, Flannery CR (2009) Modulation of lubricin biosynthesis and tissue surface properties following cartilage mechanical injury. Arthritis Rheum 60: 133-142.

Kevorkian L, Young DA, Darrah C, Donell ST, Shepstone L, Porter S, Brockbank S, Edwards DR, Parker AE, Clark IM (2004) Expression profiling of metalloproteinases and their inhibitors in cartilage. Arthritis Rheum. 50: 131-141.

Konttinen YT, Mandelin J, Li TF, Salo J, Lassus J, Liljestrom M, Hukkanen M, Takagi M, Virtanen I, Santavirta $S$ (2002) Acidic cysteine endoproteinase cathepsin $\mathrm{K}$ in the degeneration of the superficial articular hyaline cartilage in osteoarthritis. Arthritis Rheum 46: 953-960.

Kosinska MK, Ludwig TE, Liebisch G, Zhang R, Siebert HC, Wilhelm J, Kaesser U, Dettmeyer RB, Klein H, Ishaque B (2015) Articular joint lubricants during osteoarthritis and rheumatoid arthritis display altered levels and molecular species. PLoS One 10: e0125192.

Kraus VB, Burnett B, Coindreau J, Cottrell S, Eyre D, Gendreau M, Gardiner J, Garnero P, Hardin J, Henrotin Y (2011) Application of biomarkers in the development of drugs intended for the treatment of osteoarthritis. Osteoarthritis Cartilage 19: 515-542.

Li Z, Cao L, Wang S (2009). Effect of moxibustion in treating knee joint osteoarthritis and its relation with contents of hyaluronic acid in serum and synovial fluid. Zhongguo Zhong Xi Yi Jie He Za Zhi 29:883-885.

Lindhorst E, Vail T, Guilak F, Wang H, Setton L, Vilim V, Kraus V (2000) Longitudinal characterization of synovial fluid biomarkers in the canine meniscectomy model of osteoarthritis. J Orthop Res 18: 269-280.

Little CB, Hughes CE, Curti CL, Janusz MJ, Bohne R, Wang-Weigand S, Taiwo YO, Mitchell PG, Otternes IG, Flannery CR (2002) Matrix metalloproteinases are involved in C-terminal and interglobular domain processing of cartilage aggrecan in late stage cartilage degradation. Matrix Biol 21: 271-288.

Liu W, Burton-Wurster N, Glant TT, Tashman S, Sumner DR, Kamath RV, Lust G, Kimura JH, Cs-Szabo $G$ (2003) Spontaneous and experimental osteoarthritis in dog: similarities and differences in proteoglycan levels. J Orthop Res 21: 730-737.

Long DL, Willey JS, Loeser RF (2013) Rac1 is required for matrix metalloproteinase 13 production by chondrocytes in response to fibronectin fragments. Arthritis Rheum 65: 1561-1568.

Lorenz H, Wenz W, Ivancic M, Steck E, Richter W (2005) Early and stable upregulation of collagen type II, collagen type I and YKL40 expression levels in cartilage during early experimental osteoarthritis occurs independent of joint location and histological grading. Arthritis Res Ther 7: R156-R165.
Luther JK, Cook CR, Cook JL (2009) Meniscal release in cruciate ligament intact stifles causes lameness and medial compartment cartilage pathology in dogs 12 weeks postoperatively. Vet Surg 38: 520-529.

Matsukawa S, Tanimura M, Toyosaki-Maeda T, Noda A, Kobayashi M, Yamauchi A, Onoda J, Tsuji T, Takahashi T, Matsuo Y (2013) CIINE Reflects Collagenase-Specific CII Breakdown in Cartilage Explant and Whole Body of Canine. Biomark Insights 8: 77-83.

Matyas JR, Atley L, Ionescu M, Eyre DR, Poole AR (2004) Analysis of cartilage biomarkers in the early phases of canine experimental osteoarthritis. Arthritis Rheum 50: $543-552$.

Matyas JR, Huang D, Chung M, Adams ME (2002) Regional quantification of cartilage type II collagen and aggrecan messenger RNA in joints with early experimental osteoarthritis. Arthritis Rheum 46: 1536-1543.

Misumi K, Vilim V, Carter SD, Ichihashi K, Oka T, Sakamoto H (2002) Concentrations of cartilage oligomeric matrix protein in dogs with naturally developing and experimentally induced arthropathy. Am J Vet Res 63: 598-603.

Miyamoto K, Sugihara K, Abe Y, Nobori T, Tokita M, Komai $T$ (2002) Novel plasma-separation dilayer gellan-gellan-sulfate adsorber for direct removal of extra domain A containing fibronectin from the blood of rheumatoid arthritis patients. Int J Biol Macromol 30: 197-204.

Moreau M, Rialland P, Pelletier JP, Martel-Pelletier J, Lajeunesse D, Boileau C, Caron J, Frank D, Lussier B, Del Castillo J (2011) Tiludronate treatment improves structural changes and symptoms of osteoarthritis in the canine anterior cruciate ligament model. Arthritis Res Ther 13: R98.

Musumeci G, Castrogiovanni P, Trovato F, Imbesi R, Giunta S, Szychlinska M, Loreto C, Castorina S, Mobasheri A (2015) Physical activity ameliorates cartilage degeneration in a rat model of aging: A study on lubricin expression. Scand J Med Sci Sports 25: e222-e230.

Musumeci G, Trovato FM, Loreto C, Leonardi R, Szychlinska MA, Castorina S, Mobasheri A (2014) Lubricin expression in human osteoarthritic knee meniscus and synovial fluid: A morphological, immunohistochemical and biochemical study. Acta Histochem 116: 965-972.

Nagase H, Kashiwagi M (2003) Aggrecanases and cartilage matrix degradation. Arthritis Res Ther 5: 94-103.

Nganvongpanit K, Itthiarbha A, Ong-Chai S, Kongtawelert $P$ (2008) Evaluation of serum chondroitin sulfate and hyaluronan: biomarkers for osteoarthritis in canine hip dysplasia. J Vet Sci 9: 317-325.

Nia HT, Ortiz C, Grodzinsky A (2015) Aggrecan: approaches to study biophysical and biomechanical properties. Methods Mol Biol 1229: 221-237.

Nusgens B (2010) Hyaluronic acid and extracellular matrix: a primitive molecule? Ann Dermatol Venereol 137: S3-8.

Oliviero F, Sfriso P, Baldo G, Dayer J, Giunco S, Scanu A, Bernardi D, Ramonda R, Plebani M, Punzi L (2009) Apolipoprotein AI and cholesterol in synovial fluid of patients with rheumatoid arthritis, psoriatic arthritis and osteoarthritis. Clin Exp Rheumatol 27: 79-83.

Pelletier JP, Boileau C, Boily M, Brunet J, Mineau F, Geng C, Reboul P, Laufer S, Lajeunesse D, Martel-Pelletier J (2005) The protective effect of licofelone on experimental osteoarthritis is correlated with the downregula- 
tion of gene expression and protein synthesis of several major cartilage catabolic factors: MMP-13, cathepsin $\mathrm{K}$ and aggrecanases. Arthritis Res Ther 7: R1091-102.

Pelletier JP, Boileau C, Brunet J, Boily M, Lajeunesse D, Reboul P, Laufer S, Martel-Pelletier J (2004) The inhibition of subchondral bone resorption in the early phase of experimental dog osteoarthritis by licofelone is associated with a reduction in the synthesis of MMP-13 and cathepsin K. Bone 34: 527-538.

Plickert H, Bondzio A, Einspanier R, Tichy A, Brunnberg L (2013) Hyaluronic acid concentrations in synovial fluid of dogs with different stages of osteoarthritis. Res Vet Sci 94: 728-734.

Pond M, Nuki G (1973) Experimentally-induced osteoarthritis in the dog. Ann Rheum Dis 32: 387-8.

Poole AR, Ionescu M, Fitzcharles M, Billinghursta RC (2004) The assessment of cartilage degradation in vivo: development of an immunoassay for the measurement in body fluids of type II collagen cleaved by collagenases. J Immunol Methods 294: 145-153.

Pothacharoen P, Teekachunhatean S, Louthrenoo W, Yingsung W, Ong-Chai S, Hardingham T, Kongtawelert $P$ (2006) Raised chondroitin sulfate epitopes and hyaluronan in serum from rheumatoid arthritis and osteoarthritis patients. Osteoarthritis Cartilage 14: 299-301.

Prink A, Hayashi K, KIM SY, Kim J, Kapatkin A (2010) Evaluation of a collagenase generated osteoarthritis biomarker in the synovial fluid from elbow joints of dogs with medial coronoid disease and unaffected dogs. Vet Surg 39: 65-70.

Przybysz M, Borysewicz K, Kątnik-Prastowska I (2009) Differences between the early and advanced stages of rheumatoid arthritis in the expression of EDA-containing fibronectin. Rheumatol Int 29: 1397-1401.

Qi C, Changlin H (2006) Effects of moving training on histology and biomarkers levels of articular cartilage. J Surg Res 135: 352-363.

Qi C, Changlin H (2007) Levels of biomarkers correlate with magnetic resonance imaging progression of knee cartilage degeneration: a study on canine. Knee Surg Sports Traumatol Arthrosc 15: 869-878.

Rabillard M, Danger R, Doran I, Niebauer G, Brouard S, Gauthier O (2012) Matrix metalloproteinase activity in stifle synovial fluid of cranial cruciate ligament deficient dogs and effect of postoperative doxycycline treatment. Vet J 193: 271-273.

Reesink HL, Watts AE, Mohammed HO, Jay GD, Nixon AJ (2016) Lubricin/proteoglycan 4 increases in both experimental and naturally occurring equine osteoarthritis. Osteoarthritis Cartilage 25: 128-137.

Rifai N, Gillette MA, Carr SA (2006) Protein biomarker discovery and validation: the long and uncertain path to clinical utility. Nat Biotechnol 24: 971-983.

Sasaki E, Tsuda E, Yamamoto Y, Iwasaki K, Inoue R, Takahashi I, Sawada K, Fujita H, Umeda T, Nakaji $\mathrm{S}$ (2013) Serum hyaluronan levels increase with the total number of osteoarthritic joints and are strongly associated with the presence of knee and finger osteoarthritis. Int Orthop 37: 925-930.

Scanzello CR, Markova DZ, Chee A, Xiu Y, Adams SL, Anderson G, Zgonis M, Qin L, An HS, Zhang Y (2015) Fibronectin splice variation in human knee cartilage, meniscus and synovial membrane: observations in osteoarthritic knee. J Orthop Res 33: 556-562.
Schoenherr WD, MacLeay JM, Yamka RM (2010) Evaluation of body composition and cartilage biomarkers in large-breed dogs fed two foods designed for growth. Am J Vet Res 71: 934-939.

Settle S, Vickery L, Nemirovskiy O, Vidmar T, Bendele A, Messing D, Ruminski P, Schnute M, Sunyer T (2010) Cartilage degradation biomarkers predict efficacy of a novel, highly selective matrix metalloproteinase 13 inhibitor in a dog model of osteoarthritis: confirmation by multivariate analysis that modulation of type II collagen and aggrecan degradation peptides parallels pathologic changes. Arthritis Rheum 62: 3006-3015.

Šimáneka V, Křenb V, Ulrichováa J, Galloc J (2005) The efficacy of glucosamine and chondroitin sulfate in the treatment of osteoarthritis: are these saccharides drugs or nutraceuticals? Biomed Pap 149: 51-56.

Skoumal M, Haberhauer G, Feyertag J, Kittl E, Bauer K, Dunky A (2006) Serum levels of cartilage oligomeric matrix protein (COMP): a rapid decrease in patients with active rheumatoid arthritis undergoing intravenous steroid treatment. Rheumatol Int 26: 1001-1004.

Spector T, Woodward L, Hall G, Hammond A, Williams A, Butler M, James I, Hart D, Thompson P, Scot D (1992) Keratan sulphate in rheumatoid arthritis, osteoarthritis, and inflammatory diseases. Ann Rheum Dis 51: 1134-1137.

Steffey MA, Miura N, Todhunter RJ, Nykamp SG, Freeman KP, Scarpino V, Vernier-Singer MA, Erb HN, MacLeod JN, Lust G (2004) The potential and limitations of cartilage-specific $(\mathrm{V}+\mathrm{C})$ - fibronectin and cartilage oligomeric matrix protein as osteoarthritis biomarkers in canine synovial fluid. Osteoarthritis Cartilage 12: $818-825$.

Stoffels JM, Zhao C, Baron W (2013) Fibronectin in tissue regeneration: timely disassembly of the scaffold is necessary to complete the build. Cell Mol Life Sci 70: $4243-4253$.

Stone AV, Loeser RF, Vanderman K, Long D, Clark SC, Ferguson CM (2014) Pro-inflammatory stimulation of meniscus cells increases production of matrix metalloproteinases and additional catabolic factors involved in osteoarthritis pathogenesis. Osteoarthritis Cartilage 22: 264-274.

Struglics A, Larsson S, Pratta MA, Kumar S, Lark M, Lohmander L (2006) Human osteoarthritis synovial fluid and joint cartilage contain both aggrecanase-and matrix metalloproteinase-generated aggrecan fragments. Osteoarthritis Cartilage 14: 101-113.

Szychlinska M, Leonardi R, Al-Qahtani M, Mobasheri A, Musumeci G (2016) Altered joint tribology in osteoarthritis: Reduced lubricin synthesis due to the inflammatory process. New horizons for therapeutic approaches. Ann Phys Rehabil Med 59: 149-56

Taguchi M, Sun YL, Zhao C, Zobitz ME, Cha CJ, Jay GD, An KN, Amadio PC (2009) Lubricin surface modification improves tendon gliding after tendon repair in a canine model in vitro. J Orthop Res 27: 257-263.

Tesche F, Miosge N (2004) Perlecan in late stages of osteoarthritis of the human knee joint. Osteoarthritis Cartilage 12: 852-862.

Valiyaveettil M, Mort JS, McDevitt CA (2005) The concentration, gene expression, and spatial distribution of aggrecan in canine articular cartilage, meniscus, and anter- 
ior and posterior cruciate ligaments: a new molecular distinction between hyaline cartilage and fibrocartilage in the knee joint. Connect. Tissue Res 46: 83-91.

Venable RO, Stoker AM, Cook CR, Cockrell MK, Cook JL (2008) Examination of synovial fluid hyaluronan quantity and quality in stifle joints of dogs with osteoarthritis. Am J Vet Res 69: 1569-1573.

Vilar JM, Rubio M, Spinella G, Cuervo B, Sopena J, Cugat R, Garcia-Balletbó M, Dominguez JM, Granados M, Tvarijonaviciute A (2016) Serum Collagen Type II Cleavage Epitope and Serum Hyaluronic Acid as Biomarkers for Treatment Monitoring of Dogs with Hip Osteoarthritis. PLoS One 11: e0149472.

Wakitani S, Nawata M, Kawaguchi A, Okabe T, Takaoka K, Tsuchiya T, Nakaoka R, Masuda H, Miyazaki K (2007) Serum keratan sulfate is a promising marker of early articular cartilage breakdown. Rheumatology (Oxford) 46: 1652-1656.

Wei L, Fleming BC, Sun X, Teeple E, Wu W, Jay GD, Elsaid KA, Luo J, Machan JT, Chen Q (2010) Comparison of differential biomarkers of osteoarthritis with and without posttraumatic injury in the Hartley guinea pig model. J Orthop Res 28: 900-906.

Westwood R, Scott RC, Somers RL, Coulson M, Maciewicz RA (2009) Characterization of fibrodysplasia in the dog following inhibition of metalloproteinases. Toxicol Pathol 37: 860-872.

Wilke VL, Robinson DA, Evans RB, Rothschild MF, Conzemius MG (2005) Estimate of the annual economic impact of treatment of cranial cruciate ligament injury in dogs in the United States. J Am Vet Med Assoc 227: 1604-1607.

Young AA, McLennan S, Smith MM, Smith SM, Cake MA, Read RA, Melrose J, Sonnabend DH, Flannery CR, Little CB (2006) Proteoglycan 4 downregulation in a sheep meniscectomy model of early osteoarthritis. Arthritis Res Ther 8: R41.

Yun S, Ku SK, Kwon YS (2016) Adipose-derived mesenchymal stem cells and platelet-rich plasma synergistically ameliorate the surgical-induced osteoarthritis in Beagle dogs. J Orthop Surg Res 11: 9.

Zack MD, Arner EC, Anglin CP, Alston JT, Malfait AM, Tortorella MD (2006) Identification of fibronectin neoepitopes present in human osteoarthritic cartilage. Arthritis Rheum 54: 2912-2922.

Zack MD, Malfait AM, Skepner AP, Yates MP, Griggs D.W, Hall T, Hills RL, Alston JT, Nemirovskiy OV, Radabaugh MR (2009) ADAM-8 isolated from human osteoarthritic chondrocytes cleaves fibronectin at Ala271. Arthritis Rheum 60: 2704-2713.

Zhao C, Wei Z, Reisdorf RL, Thoreson AR, Jay GD, Moran SL, An KN, Amadio PC (2014) The Effects of Biological Lubricating Molecules on Flexor Tendon Reconstruction in a Canine Allograft Model In Vivo. Plast Reconstr Surg 133: $628 \mathrm{e}-637 \mathrm{e}$. 